\title{
圧縮破壊下における海永のフラクタル特性 に関する室内試験
}

\author{
竹内 貴弘 1 ・木岡 信治 2 ・成田 恭一 3 \\ 1正会員 八戸工業大学 工学部土木建築工学科（币031-8501八戸市妙大開88-1） \\ E-mail:take@hi-tech.ac.jp \\ 2正会員（独）寒地土木研究所 寒冷沿岸域チーム（干062-8602＼cjkstart札幌市豊平区平岸1条3丁目） \\ E-mail: kioka@ceri.go.jp \\ 3 (株) 丸田組 土木部（广093-0001網走市南1条東1丁目13番地3） \\ E-mail: kyouiti-n@marutagumi.co.jp
}

\begin{abstract}
海岸・海洋構造物に働く水圧力の寸法依存性は氷圧力Pと貫入面積Aの関係で示され、この説明には幾 つかのアプローチがある。その一つにPalmer and Sanderson(1991)のフラクタル理論を適用した明快な説明 があるが、この場合に必要とされる海水の圧縮破壊時のフラクタル次元Dに関しては、系統だったデータ の取得が不可欠である。本研究では、海水圧縮破壊時の水破片のフラクタル次元Dに関する室内試験を試 み、フラクタル次元Dに対するフラクタル性、氷温、密度、および結晶構造の影響を検討した。海水の圧 縮破壊時の水破片にはフラクタル性があること、結晶構造の違いや密度には影響をあまり受けないこと、 水温の影響が僅かにあること、さらにDは2.16から2.39の範囲内にあったことなどを報告した。
\end{abstract}

Key Words : fractal, scaling effect, sea ice, arctic offshore structure

\section{1. はじめに}

海岸・海洋構造物に働く水圧力の寸法依存性は非常に 重要な課題と認識され，これまでに多くの研究が行われ てきた（例えば：Sanderson ${ }^{1)}$ ）。この寸法依存性は，水 圧力P と貫入面積 $\mathrm{A}$ 関係 $\left(\mathrm{P}=\mathrm{k} * \mathrm{~A}^{\alpha}\right)$ を示すいわゆるP-A カーブで主に表現され，この勾配 $\alpha$ の多くは-0.7〜0.25にあると報告されてはいるが，設計のガイダンスと なるISO TC67 / SC7-WG8 ${ }^{2)}$ やAPI 2n/CSA ${ }^{3)}$ の記述を比較 すると，未だに整合性がとれてはいない，寸法依存性の 根拠については幾つかのアプローチがあり，中でも Palmer and Sanderson ${ }^{4)}$ のフラクタル理論を適用した明快な 説明がある。この場合には $\alpha=-0.25 て ゙ ， \mathrm{k}$ の誘導には海 水の圧縮破壊時のフラクタル次元Dが必要となるが，十 分なデータがな $<\mathrm{D}=2.5$ とし1.7を得ている（図-1）。こ の $\mathrm{k}$ は海水の破壊じん性值，最も大きい水片サイズと最 も小さい水片サイズとの比に基づく数值，水片が同様の 形状で異なったサイズのn個の水片に粉砕される確率的に 依存し、この確率ははDとnから計算できる。また, 確率 $\mathrm{p}$ と的，フラクタル性を示せば自己相似性から何れの水 片サイズにおいても一定である。これらそれぞれの水片 が与えた荷重の合計から水圧力Pを算定し貫入面積 $\mathrm{A}$

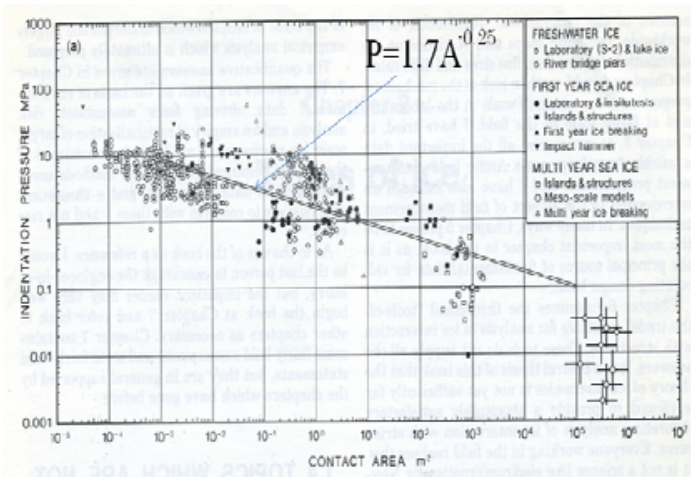

図-1Ｐalmer and Sanderson のモデルとフィールドデ 一タによる水圧力 $\mathrm{P}$ と貫入面積 $\mathrm{A}$ の関係

の関係からP-Aカーブが導かれる．他の材料に関するD の值の研究は多いが海水に関しては若干の報告(5)がある のみで，さらに系統だったデータの取得が不可欠である.

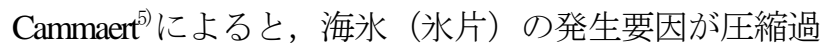
程によるものはフラクタル性を示寸が, それ以外の力学 的過程によるもや熱的な原因で発生した場合にはフラク タル性を示さないとの報告もある．本研究では，海水圧 縮破壊時の水破片のフラクタル次元Dに関する室内試験 を試み, フラクタル特性（フラクタル性, 水温, および 結晶構造の影響）に関する検討を試みた。 


\section{2. 実験とフラクタル次元Dの算定}

\section{（1） 実験方法}

写真-1や図-2のようなモールドとランマーからなる試 験装置を新たに作成し，低温室内で作成した海水供試体 （円筒形：直径 $10 \mathrm{~cm}$ ，高さ $5 \mathrm{~cm}$ ）にランマーを $10 \mathrm{~cm} の$ 高 さからN回落下させることにより圧縮破壊させた。これ で発生した水片に対し篩試験を行い（写真-2），各篩严 イズL (37.5，26.5，19，9.5，4.25，2.0，0.850mm）の 水片重量Mを其々計測することで水片の分布を求めた. 試験は全部で89ケース実施した。

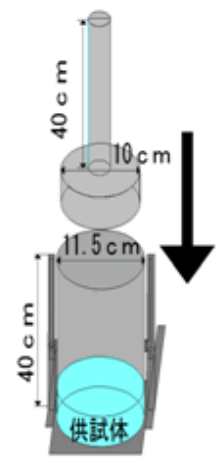

図-2 試験装置
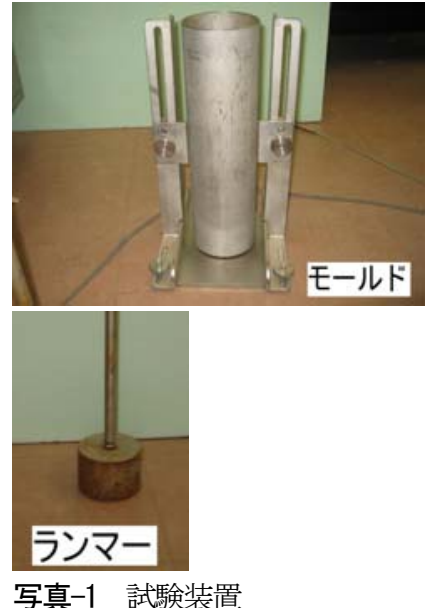

写真-1 試験装置

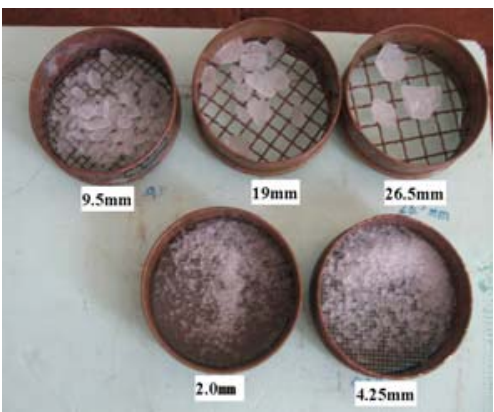

写真-2

篩試験後の水片サイズ
海水供試体の作成にあたっては，塩分濃度を1.5\%0の 塩水を $100(\mathrm{~cm}) \times 90(\mathrm{~cm})$ の水槽に高さ25 $(\mathrm{cm})$ の位置 まで入れ低温室にで約 1 週間ほど水点下 $20^{\circ} \mathrm{C} て ゙$ 結水させ 試験水（塩分濃度 $5 \%$ 程度を目標）を作成寸る。一年海 水の結晶構造図 (Schwarz\&Weeks) $\left.{ }^{6}\right)$ は図-3の様に表層部 の粒状水，それより下層の柱状水に大きく分かられるた め, 今回は試験水の表層 $3.5 \mathrm{~cm}$ 切断し，それ以下の柱状 水を水供試体とした. この時サンプリング方向によって 結晶構造が変化するためType- I （鋁直方向），Type-II (水平方向）に分けてコアリングを行った. この様にし て作成した氷供試体の結晶写真を写真-3（a）, (b) と写真 -4 (a) ,(b)に示寸.

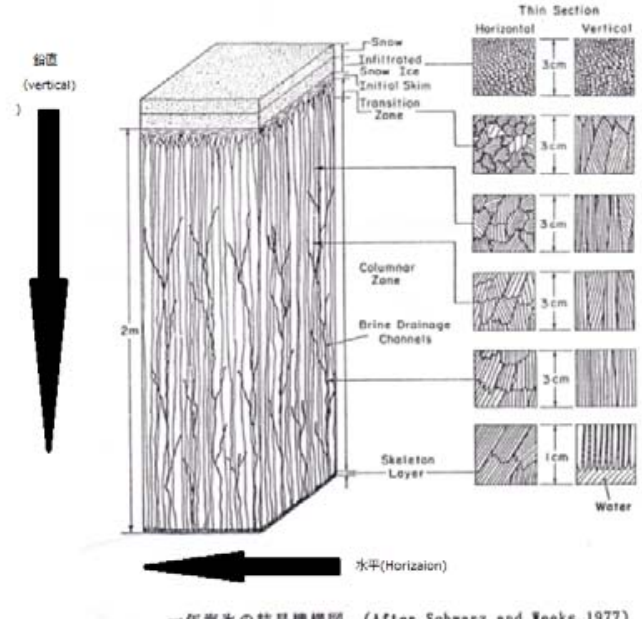

図-3 一年海水の結晶構造図（Schwarz\&Weeks,1977）

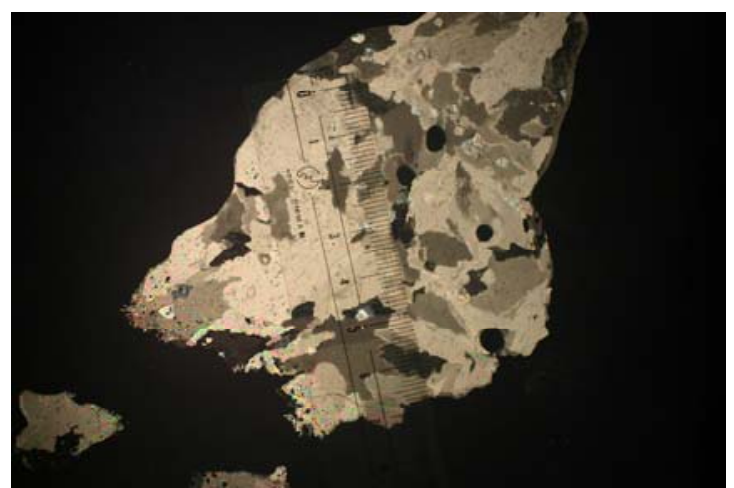

(a)

Type I 一上層 結晶写真 水平で表層から $3.5 \mathrm{~cm}$ から $8.5 \mathrm{~cm}$ (上層) の水平結晶写真. 結晶粒径 (平均) $1.1 \mathrm{~cm}$

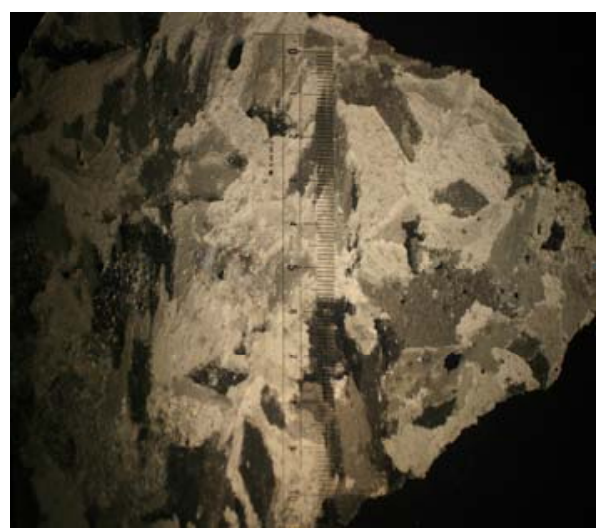

(b)

Type I -下層 結晶写真 水平で表層から $8.5 \mathrm{~cm}$ から $13.5 \mathrm{~cm}$ （下層）の水平結晶写真結晶粒径（平均） $1.64 \mathrm{~cm}$

写真-3 (a),(b) 海水供試体の結晶写真 


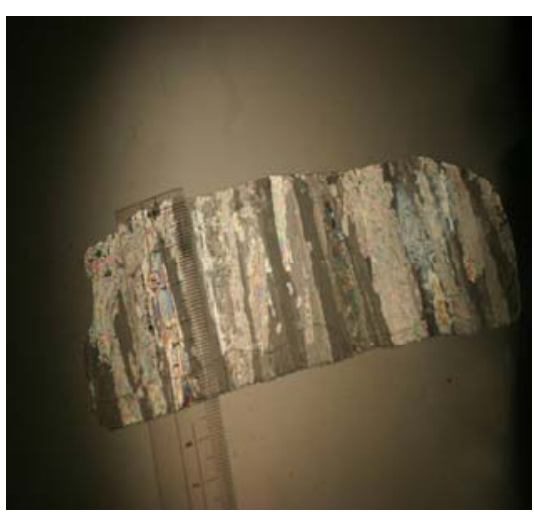

(a)

TypeII-上層 結晶写真 鉛直で表層から $3.5 \mathrm{~cm}$ から 8.5 $\mathrm{cm}$ （上層）の鉛直結晶写真

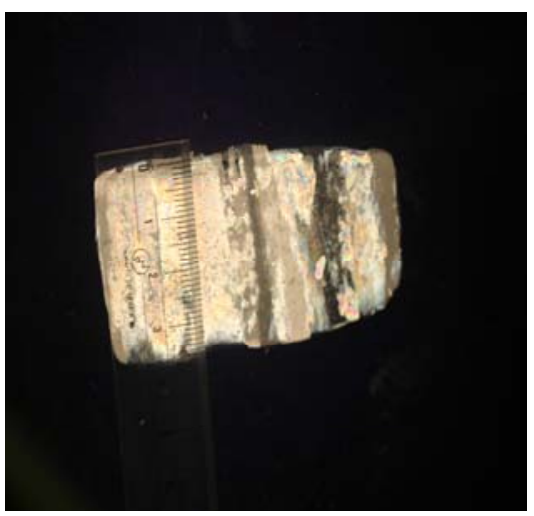

(b)

TypeII-下層 結晶写真 鉛直で表層から $8.5 \mathrm{~cm}$ から 13.5 cm（下層）の鉛直結晶写真

写真-4 (a),(b) 海水供試体の結晶写真

\section{(2) フラクタル次元Dの算定}

フラクタル次元Dは次の式(1)の累乗で示される.

$$
\frac{N\left(L_{1}\right)}{N\left(L_{2}\right)}=\left(\frac{L_{1}}{L_{2}}\right)^{-D}
$$

$\mathrm{D}$ : フラクタル次元

$\mathrm{N}\left(\mathrm{L}_{1}\right)$ : 寸法 $L_{1}$ より大きな水破片の個数

$\mathrm{N}\left(\mathrm{L}_{2}\right)$ ：寸法 $L_{2}$ より大きな水破片の個数

このDの算定に当たっては，松下党により幾つかの方 法（スケール変換法, カバー法, ボックスカウント法, 視野拡大法，回転半径法，密度相関関数法など）が示さ れている. 圧縮下で発生する水破片の場合にはそれぞれ の膨大な個数をカウントすることは適当ではなく，篩試 験からは各篩（サイズL）上の水片重量が其々計測され るため，各篩（サイズL） と水片重量Mの累積值との関 係をグラフ化し，MとLとの関係からDを求めることと した，そのためには，式(1)を式(2)の様に変形し，
土木学会論文集B3 (海洋開発), Vol. 69, No. 2, I_1192-I_1197, 2013.

$$
\frac{d N}{d L} \propto L^{-D-1}
$$

また，次に質量 $\mathrm{M}$ ，個数 N，寸法 L との関係は式(3) と なる。

$$
d M \propto L^{3} \times d N
$$

式（2）と式(3）より $\mathrm{dN}$ を消去し積分すると式(4) とな る.

$$
M \propto L^{3-D}
$$

篩試験から得られる M と L との関係である式(5) の係 数 M0, M1 を回帰式から求め, 式(6) から D を計算し た.

$$
\begin{aligned}
& M=M 0 \times L^{M 1} \\
& D=3-M 1
\end{aligned}
$$

\section{3. 実験結果}

実施した 89 ケースの試験すべてに対して M と Lとの 関係を示寸図-4の図表を作成し，その時の累乗(M1)や 相関関係 (R)を計算した. 累乗(M1) と式(6) から Dを, また，相関係数 $(\mathrm{R})$ が 1 に近いことからフラクタル性が あるかどうかを判断した．図-5(a)-(k)はＭとＬとの関係 を示すすべてのデータの図表である.

また，表-1には試験条件とフラクタル次元 D ，相関 係数 $\mathrm{R}$, 密度 $\rho\left(\mathrm{g} / \mathrm{cm}^{3}\right)$, 塩分濃度 $\mathrm{S}(\% \mathrm{o})$, 落下回数 $\mathrm{N}(10,15,20)$ を示した. また, 表中の数字は主に平均值 であり，（）内の数字はデータの範囲，【】内の数字は ケース数である.

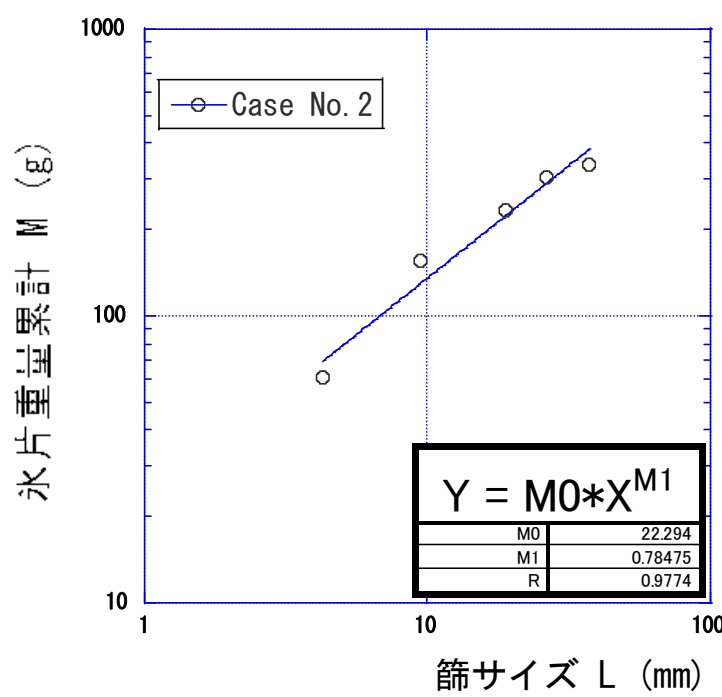

図-4 水片重量 M と篩サイズ L との関係 (case 2) 

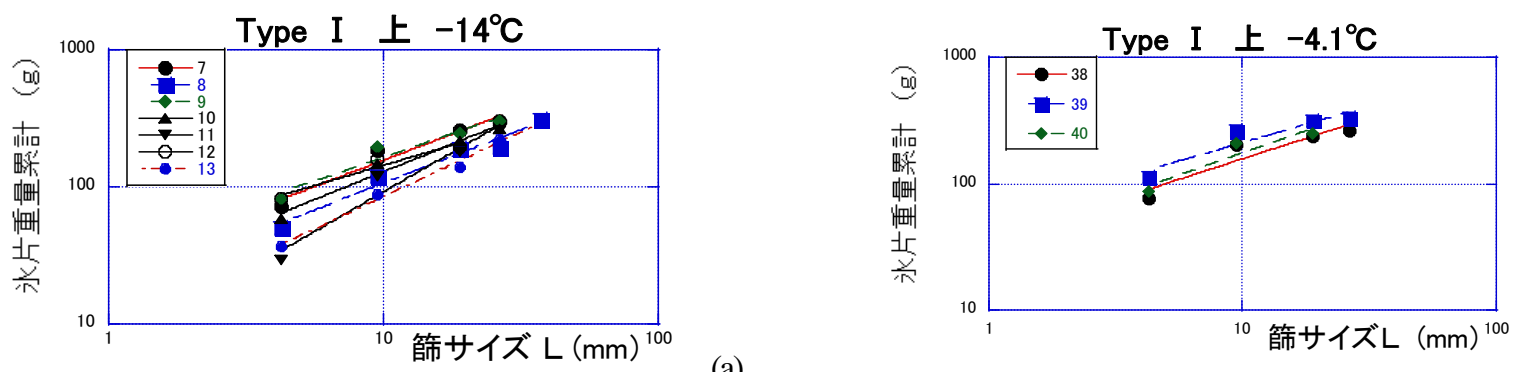

(a)

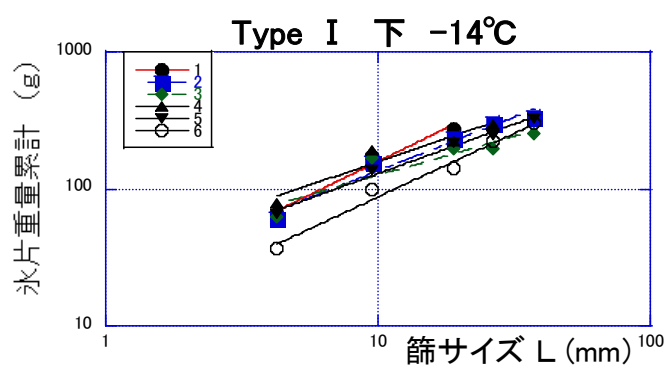

(b)
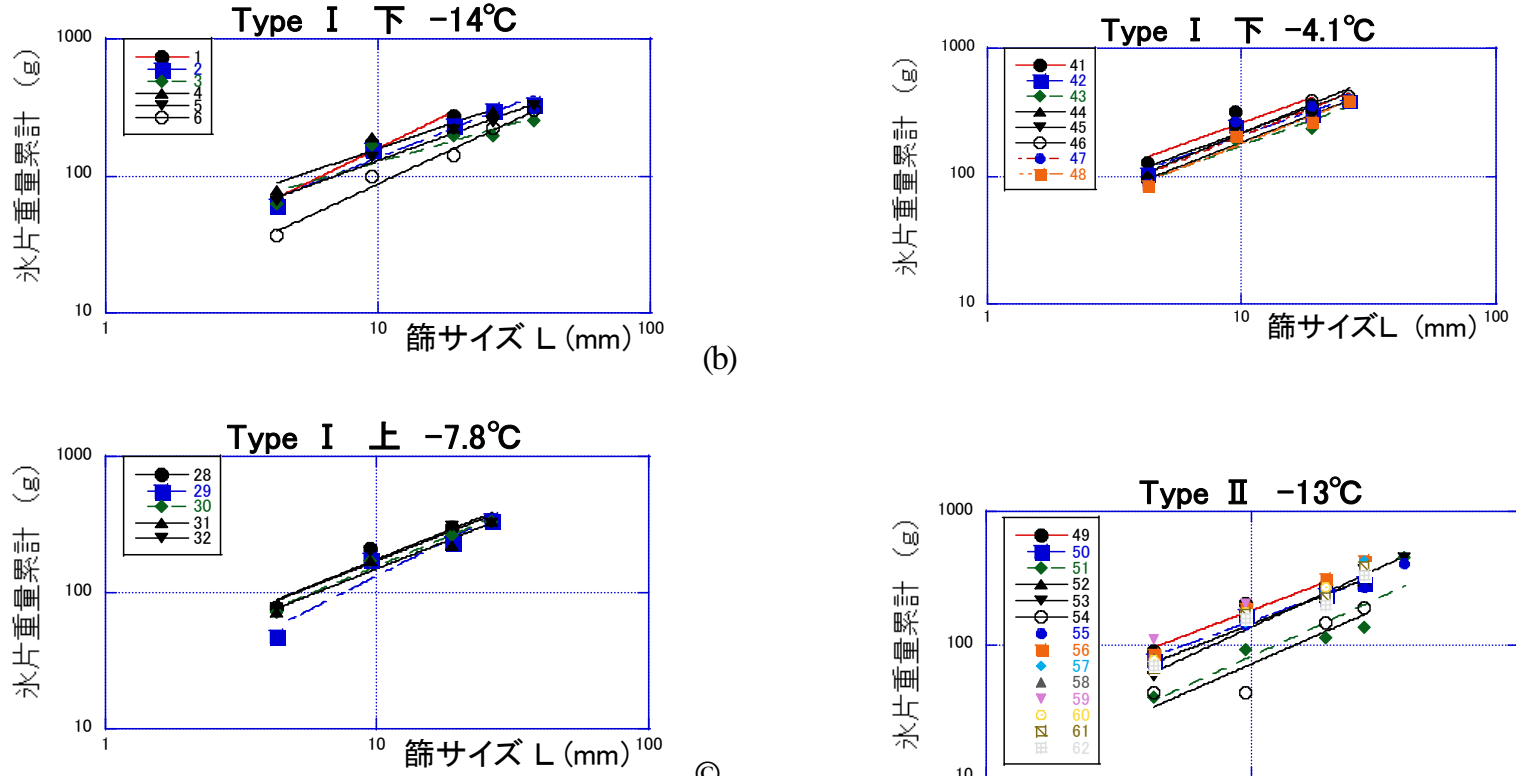

(C)

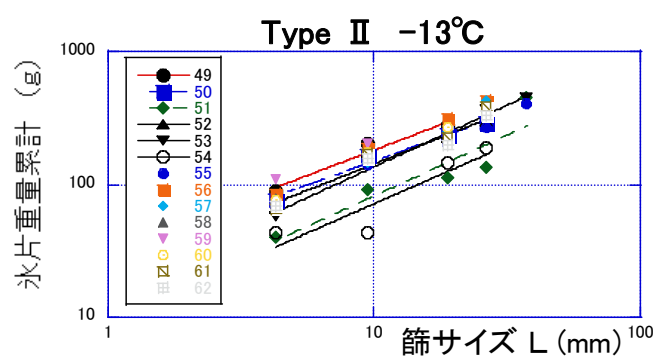

(i)

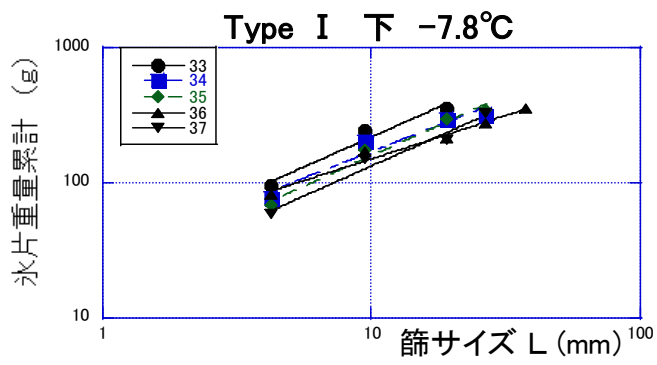

(d)

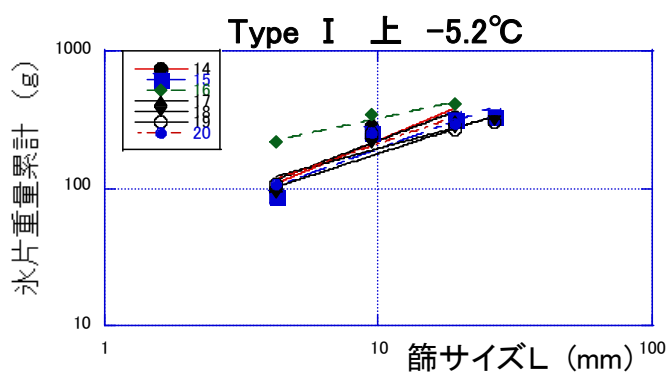

(e)
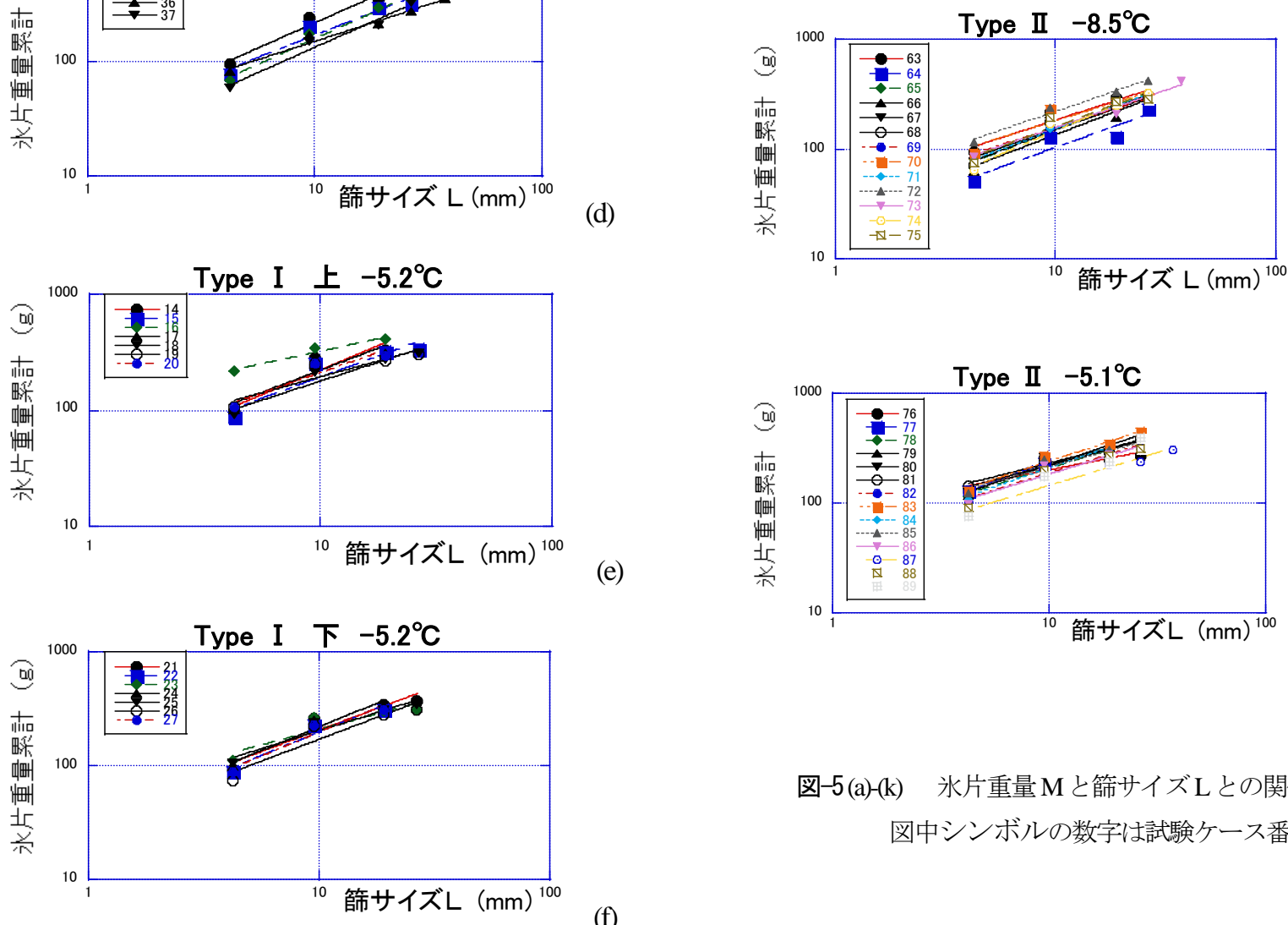

図-5(a)-(k) 水片重量 M と篩サイズ L との関係 図中シンボルの数字は試験ケース番号 
表-1 試験条件と結果

\begin{tabular}{|c|c|c|c|}
\hline $\mathrm{T} \quad{ }^{\circ} \mathrm{C}$ & & Type I 上 & ケース数 \\
\hline \multirow{5}{*}{-14} & $\mathrm{D}$ & $2.18(1.85 \sim 2.41)$ & \multirow{5}{*}{7} \\
\hline & $\mathrm{R}$ & $0.98(0.97 \sim 1)$ & \\
\hline & $\rho$ & $(0.812 \sim 0.857)$ & \\
\hline & $\mathrm{S}$ & 欠測 & \\
\hline & $\mathrm{N}$ & 10【6ケース】20【1ケース】 & \\
\hline \multirow{5}{*}{-7.8} & $\mathrm{D}$ & $2.16(1.99 \sim 2.21)$ & \multirow{5}{*}{5} \\
\hline & $\mathrm{R}$ & $0.97(0.98 \sim 1)$ & \\
\hline & $\rho$ & $(0.847 \sim 0.859)$ & \\
\hline & $\mathrm{S}$ & 7 & \\
\hline & $\mathrm{N}$ & 10【5ケース】 & \\
\hline \multirow{5}{*}{-5.2} & $\mathrm{D}$ & $2.32(2.16 \sim 2.58)$ & \multirow{5}{*}{7} \\
\hline & $\mathrm{R}$ & $0.92(0.87 \sim 0.98)$ & \\
\hline & $\rho$ & $\begin{array}{l}(0.817 \sim 0.847) \\
\end{array}$ & \\
\hline & $\mathrm{S}$ & 7 & \\
\hline & $\mathrm{N}$ & 10【7ケース】 & \\
\hline \multirow{5}{*}{-4.1} & $\mathrm{D}$ & $2.36(2.3 \sim 2.43)$ & \multirow{5}{*}{3} \\
\hline & $\mathrm{R}$ & $0.92(0.92 \sim 0.93)$ & \\
\hline & $\rho$ & $(0.842 \sim 0.852)$ & \\
\hline & $\mathrm{S}$ & 8.5 & \\
\hline & $\mathrm{N}$ & 10【3ケース】 & \\
\hline $\mathrm{T} \quad{ }^{\circ} \mathrm{C}$ & & Type I 下 & ケース数 \\
\hline \multirow{5}{*}{-14} & $\mathrm{D}$ & $2.22(2.03 \sim 2.42)$ & \multirow{5}{*}{6} \\
\hline & $\mathrm{R}$ & $0.97(0.92 \sim 0.99)$ & \\
\hline & $\rho$ & $\begin{array}{l}(0.814 \sim 0.863) \\
\end{array}$ & \\
\hline & $\mathrm{S}$ & 欠測 & \\
\hline & $\mathrm{N}$ & 10【6ケース】 & \\
\hline \multirow{5}{*}{-7.8} & $\mathrm{D}$ & $2.19(2.1 \sim 2.37)$ & \multirow{5}{*}{5} \\
\hline & $\mathrm{R}$ & $0.98(0.96 \sim 0.99)$ & \\
\hline & $\rho$ & $(0.849 \sim 0.856)$ & \\
\hline & $\mathrm{S}$ & 5.1 & \\
\hline & $\mathrm{N}$ & 10【5ケース】 & \\
\hline \multirow{5}{*}{-5.2} & $\mathrm{D}$ & $2.26(2.15 \sim 2.46)$ & \multirow{5}{*}{7} \\
\hline & $\mathrm{R}$ & $0.94(0.89 \sim 0.97)$ & \\
\hline & $\rho$ & $(0.846 \sim 0.86)$ & \\
\hline & $\mathrm{S}$ & 5 & \\
\hline & $\mathrm{N}$ & 10【7ケース】 & \\
\hline \multirow{5}{*}{-4.1} & $\mathrm{D}$ & $2.25(2.18 \sim 2.31)$ & \multirow{5}{*}{8} \\
\hline & $\mathrm{R}$ & $0.95(0.91 \sim 0.98)$ & \\
\hline & $\rho$ & $(0.813 \sim 0.854)$ & \\
\hline & $\mathrm{S}$ & 3.9 & \\
\hline & $\mathrm{N}$ & 10【8ケース】 & \\
\hline $\mathrm{T} \quad{ }^{\circ} \mathrm{C}$ & & Type II & ケース数 \\
\hline \multirow{5}{*}{-13} & $\mathrm{D}$ & $2.19(2.05 \sim 2.4)$ & \multirow{5}{*}{14} \\
\hline & $\mathrm{R}$ & $0.97(0.87 \sim 1)$ & \\
\hline & $\rho$ & $(0.824 \sim 0.849)$ & \\
\hline & $\mathrm{S}$ & 3.9 & \\
\hline & $\mathrm{N}$ & $\begin{array}{c}\text { 10【6ケース】15【5ケース】 } \\
\text { 20【3ケース】 }\end{array}$ & \\
\hline & $\mathrm{D}$ & $2.28(2.14 \sim 2.38)$ & \\
\hline & $\mathrm{R}$ & $0.97(0.92 \sim 1)$ & \\
\hline-8.5 & $\rho$ & $\begin{array}{l}0.779 \sim 0.858) \\
\end{array}$ & 13 \\
\hline & $\mathrm{S}$ & 5.7 & 13 \\
\hline & $\mathrm{N}$ & $\begin{array}{c}\text { 10【6ケース】15【4ケース】 } \\
\text { 20【3ケース】 }\end{array}$ & \\
\hline & $\mathrm{D}$ & $2.39(2.16 \sim 2.62)$ & \\
\hline & $\mathrm{R}$ & $0.96(0.88 \sim 1)$ & \\
\hline-51 & $\rho$ & $\begin{array}{l}0.812 \sim 0.858) \\
\end{array}$ & 14 \\
\hline & $\mathrm{S}$ & 7.1 & \\
\hline & $\mathrm{N}$ & $\begin{array}{c}\text { 10【6ケース】15【4ケース】 } \\
\text { 20【4ケース】 }\end{array}$ & \\
\hline
\end{tabular}

上記の様にして整理された表-1から，多くの実験で 相関係数 $(\mathrm{R})$ が 1 に近くフラクタル特性があることを確 認できた。これは Cammaert ${ }^{5)}$ の報告と対応し, 水圧力の 寸法依存性を示寸 Palmer and Sanderson ${ }^{1}{ }^{1)}$ のモデルへの適 用が可能となる. Cammaert ${ }^{5}$ は, 現地海水を用いて $-10^{\circ} \mathrm{C}$ の圧縮条件下で破砕された水破片を用い 6 ケースの実験

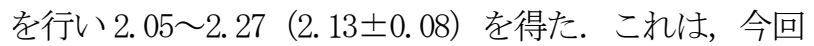
の海水の結果を平均值でみると 2.16 から 2.39 の範囲内 となり，ほぼ対応する結果となった，参考までに，湖水 （柱状水 : 鉛直・水平方向:5 ケース）では $1.75 \pm 0.06$, 湖水（雪水：水平方向: 4 ケース）では $2.08 \pm 0.02$ とな った.この結果は密度にも依存する可能性を示唆してい る.

次に, 落下回数 $\mathrm{N}$ と D 関係を試験ケース数の多い Type II で比較したものが図-6である．Dに対するNの 影響は見られない。また、水温に関しては依存性が僅か にある結果となっている.

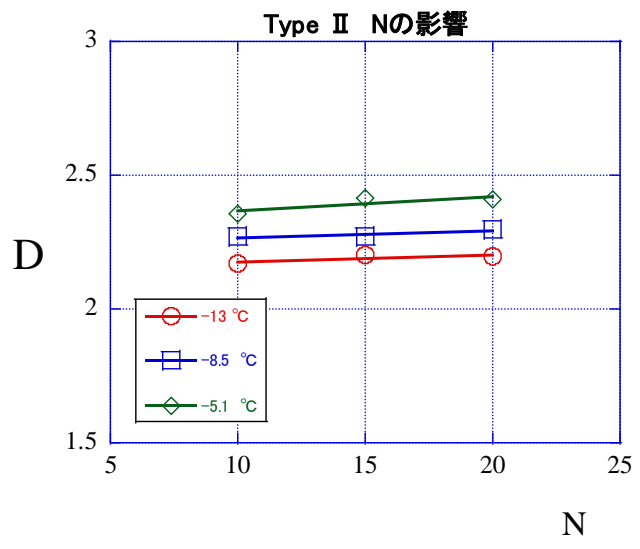

図-6 落下回数 N と D の関係(Type II)

さらに，結晶構造(Type I 上下・II)への依存性と氷温 への依存性を検討寸るためにプロットしたものが図-7 である。データはばらつくが平均值でみると結晶構造 (Type I 上下・II)の違いによる影響は見られない。また， 平均值でみると水温が大きくなるにつれ若干大きくなる 傾向を示している，参考までに最大值，最小值の範囲も 追加している.

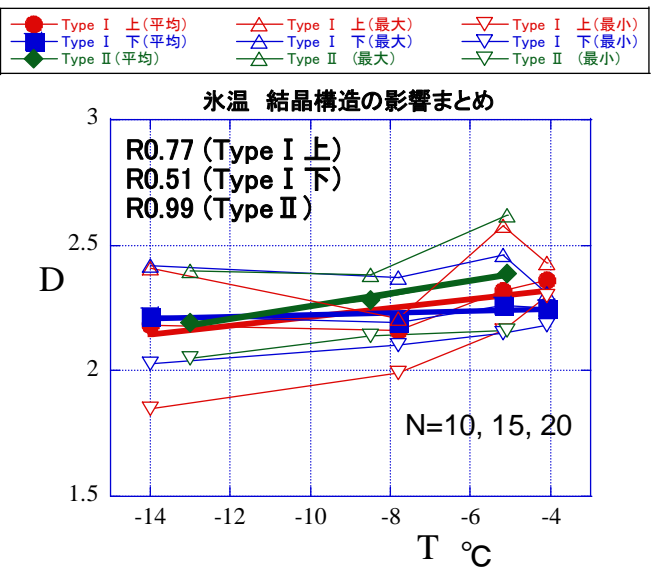

図-7 海水の結晶構造(Type I 上下・II) と水温への依存性 
次に，密度の影響を温度毎にプロットしたものが図-8 である．密度が大きくなるにつれDは若干減少する傾向 を示している様であるが，相関は非常に小さい.

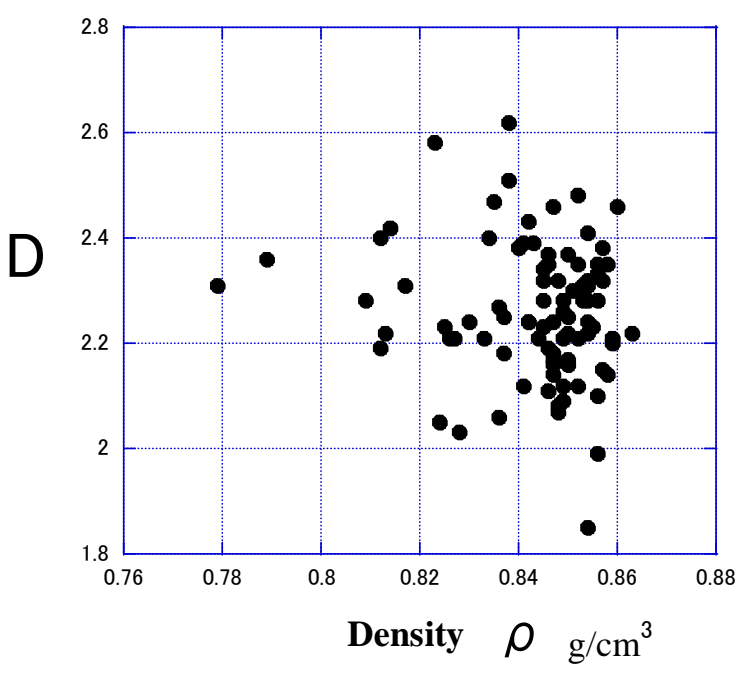

図-8Ｄ密度への依存性

\section{4. まとめ}

各試験条件下で得られた D や $\mathrm{R}$ の平均值で評価する と次の結果となる.

(1) 海水の圧縮破壊時のフラクタル次元 D は，表-1 の 相関係数 R が 1 に近いことから $\log \mathrm{M}$ と $\log \mathrm{L}$ とがほ とんどの場合直線的な相関関係を示し，フラクタル 性があると判断される.

(2) 落下回数 N と D の関係から，Dに対する $\mathrm{N}$ の影響 は見られない.

(3) 結晶構造(Type I 上下, Type II)毎に分類した水温 $\mathrm{T}$ と Dとの関係から，結晶構造の違いはDに対して
顕著な影響を示さない. また，氷温 $\mathrm{T}$ の上昇に伴つ て D僅かに増加する傾向を示した。 また，水温 $\mathrm{T}$ への影響は図-6からも同様のことが分かる.さらに、 密度への依存性は僅かなものであった。

(4) 以上のデータから，Dは2.16から 2.39 の範囲内にあ り, Cammaert ${ }^{5)}$ が-10 $\mathrm{C}$ の現地海水を用いて得た 2.05 〜2.27（2.13士0.08） とほぼ対応する結果となった。 今後は，上記の值を水盤貫入試験時に発生した氷片と も比較検討し, Palmer and Sanderson ${ }^{4)}$ ら氷圧力モデルへ 適用する予定である。また，試験条件を広げ氷温 $\mathrm{T}$ の影 響を検討する必要ある。

謝辞 : 試験データの取得に当り当時学生であつた中野倫 希氏（八戸工業大学工学部）にご協力を得ました. 記し て感謝の意を表します。

\section{参考文献}

1) Sanderson, T. J. O. : A Pressure-Area Curve ffor Ice, Proc. $7^{\text {th }}$ of IAHR Symp. On IceStructure Interaction, Vol.2, pp.361-384, 1986.

2) Petroleum and natural gas industries, Arctic offshore structures, ISO/TC 67/SC 7, ISO/DIS 19906, 2010.

3) American Petroleum Institute (API) Recommended Practice or Planning, Designing, and Constructing Structures and Pipelines for Arctic Conditions - 2N. Second Edition, 1995.

4) Palmer, A. C. and Sanderson, T. J. O. : Fractal Crushing of Ice and Brittle Solids, Proc. R. Soc. Lond. A June 8, pp.469-477, 1991.

5) Cammaert, A.B. and Crocker, G.B. : Fractal characteristics of ice, Proc. Of Port and Ocean Engineering under Arctic Conditions (POAC), pp.401-415, 1991.

6) Schwarz,J. and Weeks, W.F.:Engineering properties of sea ice, Journal of Glaciology 19(81), pp.499-531, 1977.

7) 松下貢 : フラクタルの物理（ I ），pp.28-61，裳華房 フィジックスライブラリー, 2002.

\title{
INDOOR TESTS ON FRACTAL CHARACTERISTICS OF SEA ICE PRODUCERD BY CRUSHING FAILURE
}

\author{
Takahiro TAKEUCHI, Shinji KIOKA and Kyouichi NARITA
}

The scaling effect of ice load acting on offshore structure is shown through the relation between ice pressure and indentation area, and there have been several explanations on the effect. Although there is clear explanation which applied the fractal theory of Palmer and Sanderson (1991) to one of them, there is little data of fractal dimension D. Systematic tests on fractal dimension D are required by the use of sea ice fragments produced by crushing failure.

In the research, indoor tests on D are conducted to examine fractal characteristics. There exists fractal properties on sea ice fragments produced by crushing failure, and very little dependence of ice temperature on D. The effect of density and crystal structure on D is little. Tests data on D ranges from 2.16 to 2.39 . 